\title{
EHMTI-0273. Onabotulinotoxin type A is a therapeutic option in chronic cluster headache
}

\author{
N Mas-Sala*, M Quintana, J Alvarez-Sabin, P Pozo-Rosich \\ From 4th European Headache and Migraine Trust International Congress: EHMTIC 2014 \\ Copenhagen, Denmark. 18-21 September 2014
}

To analyse the efficacy of Onabotulinumtoxin type A (OnabotA) in chronic cluster headache patients.

Six patients ( 5 men and 1 woman) diagnosed with refractory chronic cluster headache were included. Data regarding the characteristics of the headache, the frequency and the duration of the attacks, the presence of family history of migraine and the analgesic use were collected. The patients continued with their usual preventative treatment.

In 4 of the 6 patients included (66.6\%), we have observed a clear improvement in the frequency of the headache with a change in the pattern (from chronic to episodic). All of these had family history of migraine. In one of the patients no improvement was observed, and one patient was lost during follow-up.

The use of OnabotA could be considered as a therapeutic option in those patients with chronic cluster headache which are intolerant or refractory to the known and used preventative treatments, before using more invasive treatments. Larger series are needed to confirm these findings.

Submit your manuscript to a SpringerOpen ${ }^{\bullet}$ journal and benefit from:

- Convenient online submission

- Rigorous peer review

- Immediate publication on acceptance

- Open access: articles freely available online

- High visibility within the field

- Retaining the copyright to your article

Submit your next manuscript at $>$ springeropen.com

\section{SpringerOpen $^{\odot}$}

(C) 2014 Mas-Sala et al; licensee Springer. This is an Open Access article distributed under the terms of the Creative Commons Attribution License (http://creativecommons.org/licenses/by/2.0), which permits unrestricted use, distribution, and reproduction in any medium, provided the original work is properly cited. 